UDC 546.26-162:539.58

Y. Wang (Rochester, USA)

K. K. M. Lee (New Haven, USA)

\title{
From soft to superhard: fifty years of experiments on cold-compressed graphite
}

In recent years there have been numerous computational studies predicting the nature of cold-compressed graphite yielding a proverbial alphabet soup of carbon structures (e.g., bct- $C_{4}, K_{4}-, M-, H-, R-, S-, T-, W$ - and Z-carbon). Although theoretical methods have improved, the inherent nature of graphite (i.e., low-Z) and the subsequent room-temperature, high-pressure phase transition (i.e., low symmetry, nanocrystalline and sluggish), make experimental measurements difficult to execute and interpret even with the current technology of 3rd generation synchrotron sources. The room-temperature, high-pressure phase transition of graphite has been detected by numerous kinds of experiments over the past fifty years, such as electrical resistance measurements, optical microscopy, X-ray diffraction, inelastic X-ray scattering, and Raman spectroscopy. However, the identification and characterization of highpressure graphite is replete with controversy since its discovery more than fifty years ago. Recent experiments confirm that this phase has a monoclinic structure, consistent with the M-carbon phase predicted by theoretical computations. Meanwhile, experiments demonstrate that the phase transition is sluggish and kinetics is important in discerning the phase boundary. Additionally, the post-graphite phase appears to be superhard with hardness comparable to that of diamond.

Keywords: high-pressure graphite, post-graphite phase, phase transition, M-carbon, diamond-anvil cell experiments.

\section{INTRODUCTION}

From astronomy to mineralogy and zoology, carbon is one of the most important elements in nearly every field of science. Carbon is the fourth most abundant element by mass in the universe after hydrogen, helium, and oxygen [1]. The abundance of carbon along with its extraordinary ability to form diverse organic compounds under conditions commonly encountered on Earth makes carbon the essential basis for all known organic life. As such, carbon is the second most abundant element by mass in the human body, after oxygen [2]. Furthermore, carbon plays a critical role in many global issues: the carbon cycle is an integral part of climate change [3] as well as worldwide energy challenges [4].

Pure carbon exists in several forms with vastly different properties. Diamond is the most well-known form, as it is the hardest known naturally occurring material with the highest shear modulus (strongest resistance to fail under shear stress) [5]. In its pure form, diamond is a good conductor of heat, although being covalently bonded, diamond is a poor electrical conductor [6]. The diamond structure incorporates a network of covalent tetrahedral $s p^{3}$ bonds between atoms. Due to the high symmetry of this structure (Fig. 1,a) and strength of the neighboring carbon bonds, diamond is extremely isotropic and transparent over wide ranges of the electromagnetic spectrum [6]. On the other hand, graphite exhibits properties remarkably different from diamond: graphite is opaque in appearance and is a 
semi-metal with highly anisotropic material properties. Graphite's hexagonal structure consists of parallel planes of covalent hexagonally $s p^{2}$ hybrid-bonded networks of carbon atoms layered in an $\mathrm{AB}$ sequence [7] (Fig. 1, $b$ ). The layers in graphite are weakly bonded by van der Waals forces, and the anisotropy is the direct result of the difference between inter- and intra-planar bonding [8]. Along any direction parallel to the hexagonal planes ( $a$ and $b$ axes), graphite is extremely hard, and conducts electricity and heat well [8]. Along the perpendicular direction (or $c$-axis), graphite is much more compressible, and has smaller thermal conductivity and larger electrical resistivity values. The electrical resistivity measured along the $c$-axis is $\sim 10^{2}$ to $10^{5}$ times larger than that of the $a$ axis [7]. All of these differences are attributed to the unique atomic bonding structures of planar $s p^{2}$ in graphite and three-dimensional $s p^{3}$ hybridization in diamond.

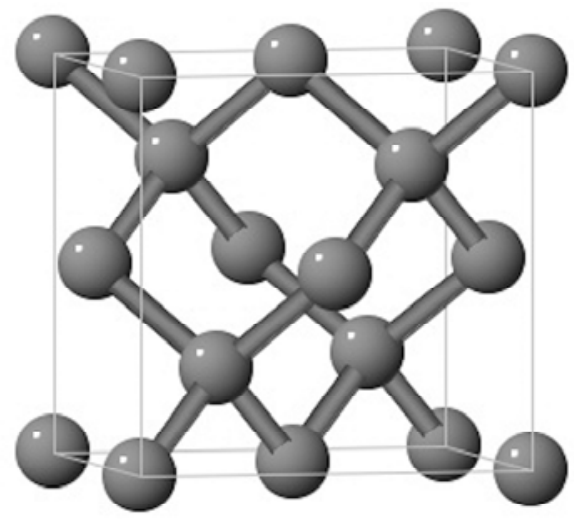

$a$

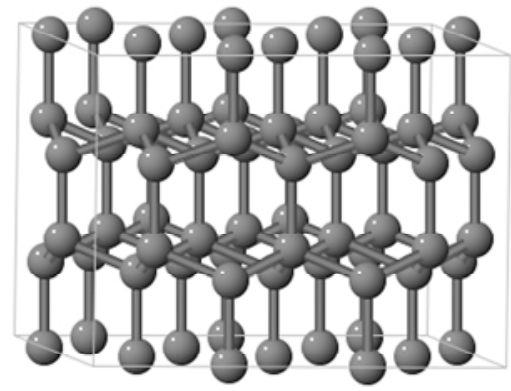

$c$

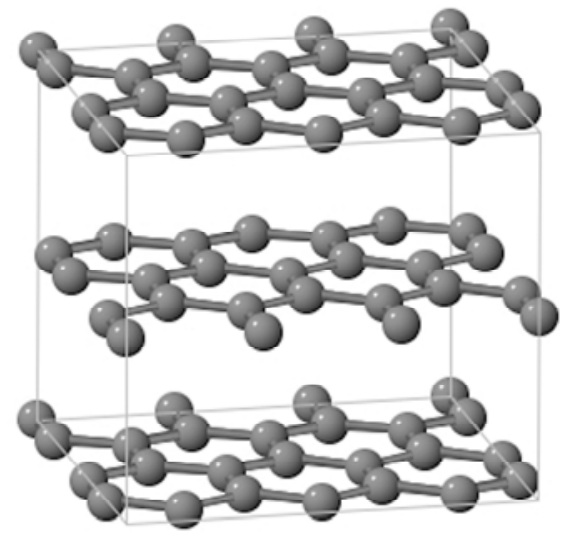

b

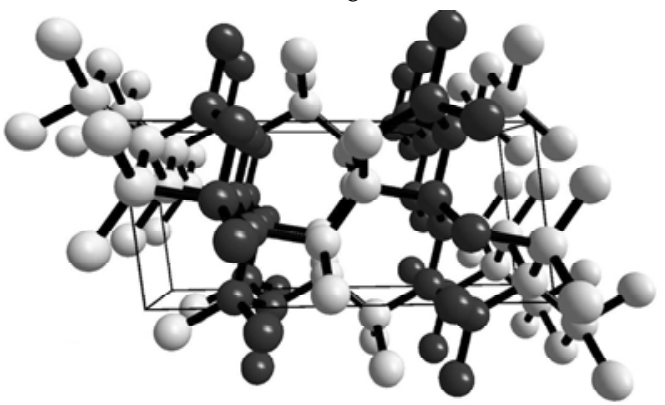

$d$

Fig. 1. Crystal structures of carbon. Diamond $(a)$, graphite $(b)$, hexagonal diamond (lonsdaleite) $(c)$, and M-carbon $(d)$. Figures $(a-c)$ are reproduced from the U.S. Naval Research Laboratory website [70] and $(d)$ is reproduced from [16].

Graphite is the most stable phase of carbon under ambient conditions, while diamond is a metastable phase. However, because the driving force to transform diamond into graphite is small, the rate of the transition is negligible and thus, the diamond to graphite transition does not spontaneously occur at ambient conditions. The transition from graphite to diamond can occur only when subjected to high pressures and temperatures and usually a catalyst is required due to the slow kinetics [9]. For example, natural diamond is formed from carbon-bearing minerals buried in the Earth's upper mantle at pressures between 4.5 and 6 GPa $(\sim 135-$ $185 \mathrm{~km}$ depth) and at temperatures between $900-1300{ }^{\circ} \mathrm{C}$ [10]. Due to diamond's relative scarcity, desirable properties and beauty, it has long been treasured as a 
precious gemstone. The situation of diamond's scarcity changed when General Electric first synthesized diamond in the 1950s by duplicating the reaction conditions (high pressures and temperatures) of natural diamond in the Earth [9, 11]. With the increased yield, diamond has been extensively used and has generated revolutionary impacts in industry and science alike.

Although graphite and diamond are the most commonly known forms of carbon, under appropriate pressure and temperature conditions, there are several other forms of carbon. Hexagonal diamond, also known as lonsdaleite (Fig. 1, c), has been found in carbon-rich meteorites, notably the Canyon Diablo iron meteorite [12], and is expected to have been formed in the high-pressure, hightemperature shock conditions of an impact, as inferred from laboratory measurements [13].

As graphite transforms into diamond (either cubic or hexagonal) under highpressure and high-temperature conditions, straightforward questions naturally arise: what occurs if graphite is placed in a high-pressure environment without heating? Are diamond-like materials still produced? What is the post-graphite structure? What are its physical properties? How does its strength to diamond? Can it be synthesized more easily than diamond? Unlike the transition from graphite to diamond under high pressures and high temperatures, the cold-compressed behavior of graphite has been an enigma for over fifty years. In this review, a detailed history of the study of graphite under high pressure and room temperature will be given, beginning with the observation of the pressure-induced phase transition in graphite through numerous characterization techniques, controversial identification of the high-pressure graphite phase, long-term efforts to solve this discrepancy, and securing an elegant solution to this enigma on the basis of comparison of experimental results with existing theoretical computations [e.g., 14, 15]. Further, the high-pressure room-temperature phase transition of graphite is sensitive to the form of the starting materials [16-18]. For this reason, we focus on crystalline hexagonal graphite, rather than amorphous graphite, fullerenes or carbon nanotubes. For a review of these carbon materials, please see the other sections in this special issue [19-21]. Additionally, there have been several reviews on the high-pressure, high-temperature behavior of carbon [22-25], however, in this review, we pay special attention to the long-standing controversies on the structural transitions of graphite at high pressures under room temperature conditions as shown through experiments.

\section{HIGH-PRESSURE ROOM-TEMPERATURE PHASE TRANSITION}

\section{Resistivity measurements}

In 1962, Samara and Drickamer [26] first observed the room-temperature transition of graphite at approximately $10 \mathrm{GPa}$ by measuring a jump in the resistivity, although this observation was not universal and depended on the nature of the starting material (powdered vs. pyrolytic) and along which axis the measurements were taken ( $a$ vs. $c$ ). Using a specifically-designed high-pressure electrical resistance cell [27] Aust and Drickamer [28] measured a large increase in resistance above $\sim 17 \mathrm{GPa}$, measuring samples of single-crystal graphite oriented in both the $a$ and $c$ directions, respectively. At the transition, the $a$-axis resistance increased by more than two orders of magnitude, while the $c$-axis resistance increased by a factor of 4 (Fig. 2). The transition was observed only in singlecrystal graphite samples, and was not observed in powdered graphite. Furthermore, 
this transition showed a large hysteresis: the resistance did not decrease again upon decompression to $\sim 7 \mathrm{GPa}$, where data collection ceased.

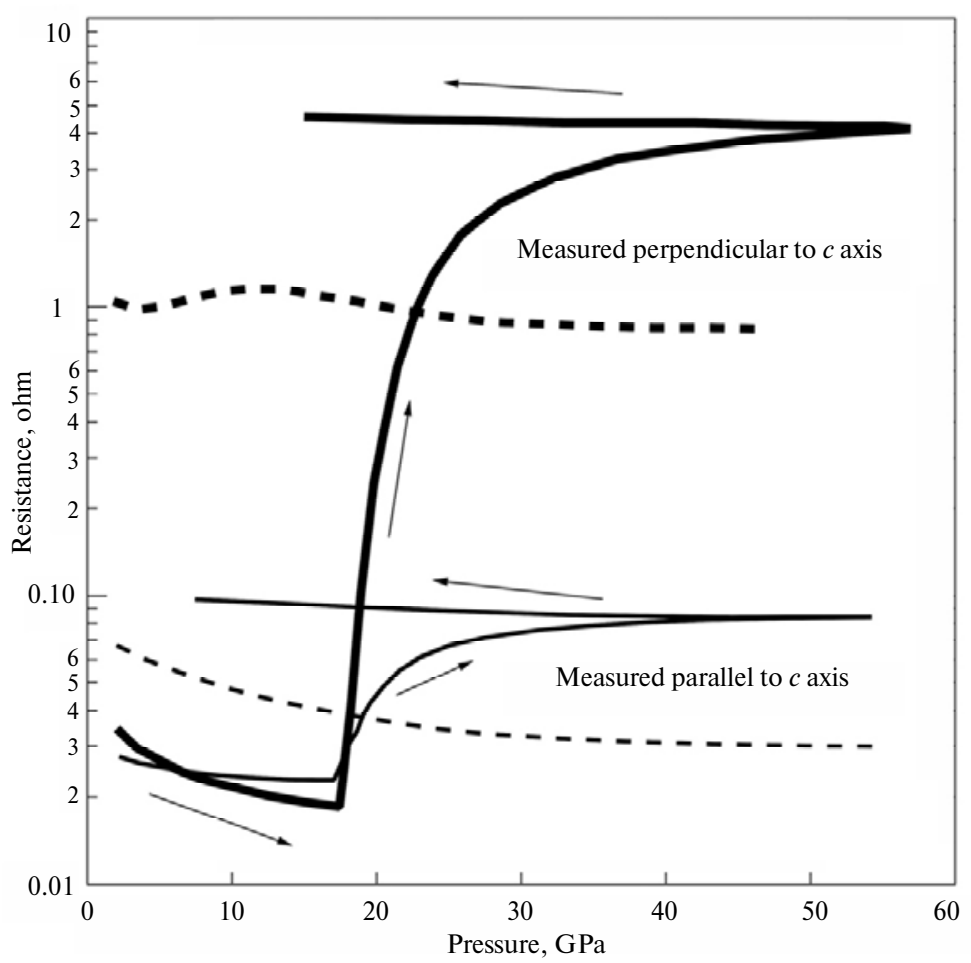

Fig. 2. Resistance of graphite vs. pressure for single-crystal graphite (solid lines) and a pyrolytic graphite (dashed lines) as measured in both parallel (thin lines) and perpendicular (thick lines) orientations to the $c$-axis. The arrows denote the sequence of pressure paths. Note the large hysteresis in the data: the resistances do not revert to low-pressure values upon decompression, at least to pressures of $\sim 15$ and $\sim 7 \mathrm{GPa}$ in measurements perpendicular and parallel to the $c$-axis, respectively. Data reproduced from [28].

Soon after, another high-pressure phase identified as hexagonal diamond, or lonsdaleite (Fig. 1,c), was investigated by Bundy and Kasper [13] while exploring the transition between graphite and diamond (see X-ray Diffraction section). Hexagonal diamond forms at temperatures greater than $1000^{\circ} \mathrm{C}$ and pressures higher than $13 \mathrm{GPa}$, implying that the phase found by Aust and Drickamer [28] was not lonsdaleite, and instead the phase partially synthesized by Aust and Drickamer has since been referred to as "cubic" graphite. In these studies, Bundy and Kasper [13] determined that chemical purity of the graphite samples did not matter, but crystalline order did: the transition occurred in well-ordered samples, but did not occur in poorly-ordered graphite, consistent with earlier measurements [28]. They also reported a similar hysteresis as observed by Aust and Drickamer [28], but ultimately observed a decrease in resistance upon depressurization below approximately $7 \mathrm{GPa}$.

Since then, several studies have been performed on cold-compressed graphite using a variety of high-pressure devices. In 1971, Okuyama et al. [29] performed room-temperature, high-pressure resistance measurements on graphite, but observed the transition in only a few samples: a synthetic sample annealed (prior to compression) to $\sim 3500 \mathrm{~K}$ and a natural Madagascar sample at 17 and $16 \mathrm{GPa}$, respectively. The transition was not observed in synthetic samples annealed at 
temperatures less than $\sim 3100 \mathrm{~K}$ at least up to pressures of $\sim 25 \mathrm{GPa}$, suggesting that higher-temperature annealing induces higher order in synthetic samples. In 1994, Li and Mao [30] performed a series of high-pressure resistivity experiments in a multi-anvil press [31], where they measured polycrystalline graphite samples and amorphous carbon, and in a diamond-anvil cell [32] (DAC), where only graphite was measured. No transition was found in amorphous carbon, where order is lacking, but transitions similar to previous graphite experiments were seen in both the multi-anvil and DAC experiments at approximately $20 \mathrm{GPa}$. The DAC experiment also confirmed the previously observed hysteresis in the resistance behavior upon decompression [30].

Earlier studies focused on the abrupt increase in the resistance of graphite with increasing pressure as an indication of a phase transition and found varying transition pressures $(\sim 10-20 \mathrm{GPa})$ with a large hysteresis. However, more recently, resistivity measurements in a DAC have been used to study the kinetics of this phase transition looking at the rate of change in the resistance prior to, during, and following the transition both on compression and decompression at room temperature [33]. These long-duration experiments, completed over the course of tens of days to capture the sluggish behavior, pinned the phase transition of highlyordered pyrolytic graphite (HOPG) to the post-graphite phase to occur at $19 \pm 2 \mathrm{GPa}$ with little hysteresis.

\section{Optical measurements}

Another observation of the sluggishness of the phase transformation of graphite under high pressures was reported by Utsumi and Yagi [34], in which the starting material was a very thin $(\sim 1 \mu \mathrm{m}$ in thickness $)$ single crystal of graphite. This observation confirmed the first reports of transparency of high-pressure graphite given by earlier studies [35-37]. The Utsumi and Yagi [1991] sample was compressed in a DAC with a mixture of methanol and ethanol as the pressure medium, and the change of the transparency of the sample with pressure was studied through in situ optical microscopy (Fig. 3). Under compression, the sample did not exhibit any noticeable change until the pressure reached $18 \mathrm{GPa}$, at which a few light-transparent spots appeared in the sample. The presence of the transparent (i.e., decreased optical reflectivity) spots indicated the creation of a high-pressure phase inside the graphite sample, in agreement with previous results [38]. As the sample was kept at this pressure, more light-transparent spots appeared and spread across the whole sample chamber. After 2 hours, the entire sample became transparent. This transparent phase is only quenchable to room conditions if heated while at high pressure, thus becoming hexagonal diamond [13]. Otherwise, the unheated and transparent post-graphite phase reverts back to its original opaque character upon quench even if compressed to pressures as high as $50 \mathrm{GPa}$.

Although sample thickness was too large to see full transparency $(\sim 13 \mu \mathrm{m}$ at the highest compressions), Montgomery et al. [33] also observed a reversion from transparent to opaque after decompression from pressures as high as $\sim 28 \mathrm{GPa}$. Miller et al. [39] confirmed these room-temperature observations as well, but also found that the phase is quenchable at temperatures below $100 \mathrm{~K}$, and proposed the mechanism behind the transition: a transfer of bonds from the graphite $s p^{2}$ hybrid bonds to the $s p^{3}$ hybrid bonds associated with diamond. This mechanism has been subsequently confirmed by inelastic X-ray scattering [40].

Recently, a new study was carried out to investigate the kinetics of the phase transition in HOPG [16]. The study found that at $19.8 \mathrm{GPa}$ after 1 hour, a few dark spots appeared on the surface of sample while viewed under reflecting light, and 
with time the concentration of the dark spots increased (Fig. 4). After 93 hours at 19.8 GPa, most of the sample became dark. This observation is consistent with the previous observations of transparency of the post-graphite phase [34] (Fig. 3), and both reveal that the phase transition of graphite under cold compression is slow and requires a long time to complete the transition. In the more recent experiment [16], although the sample did not become transparent, this is due to the increased thickness of the sample [34]. The earlier study had a thickness of $\sim 1$ micron as compared to the latter study thickness of at least an order of magnitude greater. In both cases, however, the once reflecting and electrically conducting material became insulating: the former became transparent and the latter became non-

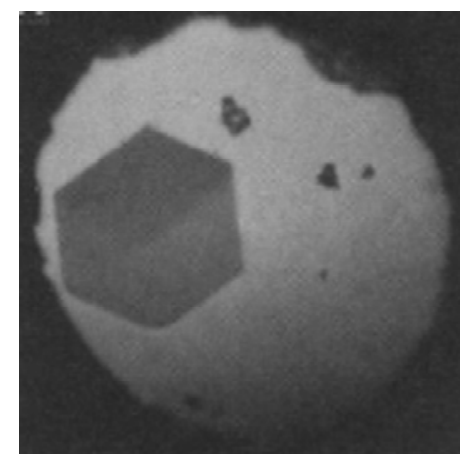

$a$

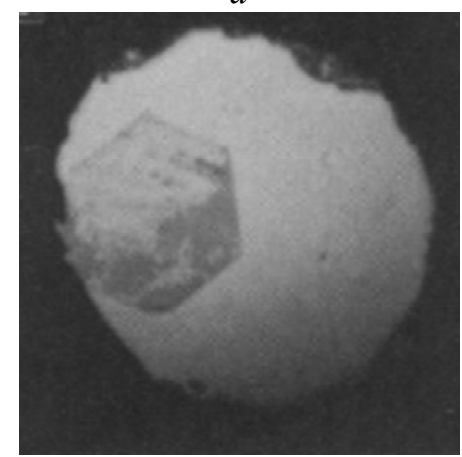

$c$

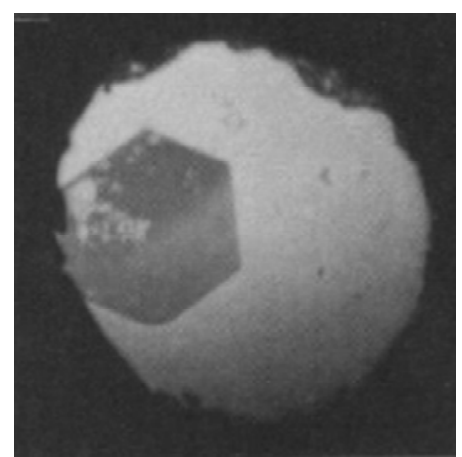

$b$

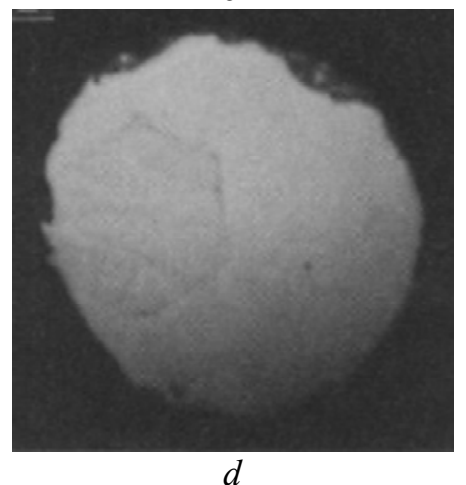

Fig. 3. The evolution of light transmission through a thin single crystal of graphite at room temperature over an extended period of time. The starting sample at ambient pressure $(a)$. At $18 \mathrm{GPa}$, the transparent spots appear in the sample $(b)$. After 30 minutes with pressure held at $18 \mathrm{GPa}$, more transparent spots accumulate across the sample area $(c)$. After 2 hours, the whole sample transforms into a new phase with high light transparency $(d)$. Reproduced from [34].

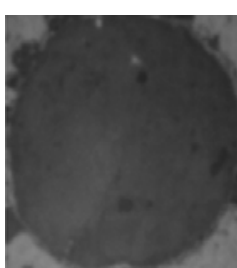

$a$

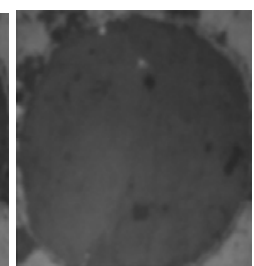

$b$

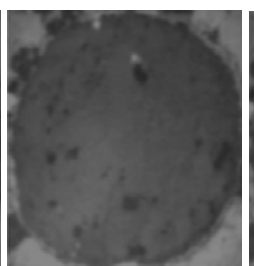

$c$

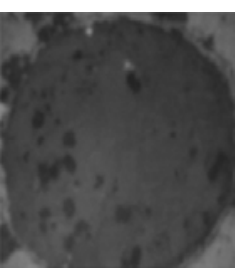

$d$

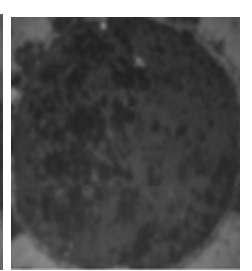

$e$

Fig. 4. Phase evolution of compressed graphite vs. relaxation time. Photomicrographs $(a)$ and $(b)$ taken immediately at pressures of 6.9 and $19.8 \mathrm{GPa}$, respectively. The dark spots in $(a)$ and $(b)$ are from ruby chips. Images $(c-e)$ captured at a pressure of $19.8 \mathrm{GPa}$ after relaxation times of 1 , 51 , and 93 hours, respectively. Figure reproduced from [16]. 
reflecting. Under high pressures, the new spots (whether transparent [34] or dark [16]) represent the nucleation and growth of the new phase and suggest that the high-pressure post-graphite phase is less conductive than graphite as demonstrated in other studies $[36,38]$.

These optical properties of graphite under high pressure reveal that the phase transition in graphite is sluggish and that long periods of time are needed to explore this phase transition.

\section{Spectroscopy}

There have been several spectroscopic studies of graphite under high-pressure conditions, which, however, are limited to DAC or gem-anvil cell (GAC) [41] experiments. DAC studies are limited due to the large signal from the diamond anvils themselves and overlap with potential signal from the post-graphite phase. Graphite has a characteristic Raman peak at $\sim 1581 \mathrm{~cm}^{-1}$ ("G" band) at ambient conditions. With increasing pressures, this peak shifts to higher wavenumbers and broadens [35, 37, 41-44], effectively disappearing at high pressures [16]. Using a GAC, specifically equipped with sapphire anvils, Xu et al. [41] confirmed that high-pressure phase transition in graphite occurs, however, the Raman spectra were not conducive to either hexagonal or cubic diamond. Upon quenching to room temperature, the $\mathrm{G}$ band returns along with broad $\mathrm{D}$ and $\mathrm{D}^{\prime}$ bands at $\sim 1350$ and $\sim 1620 \mathrm{~cm}^{-1}$, respectively [16] consistent with a reversion to sub-micron sized graphite particles [45-47], suggesting that the post-graphite phase transition causes a grain size reduction [16].

\section{X-ray diffraction}

The high symmetry of graphite (hexagonal, $P 6_{3} / m m c$ ) and comparably soft nature yield sharp and intense X-ray diffraction (XRD) peaks despite the low-Z character of carbon. As such, there are several XRD studies of graphite under pressure that show the highly anisotropic nature of hexagonal graphite $[42,48-50]$ : the $c$ axis is approximately 35 times more compressible than the $a$-axis (Table 1).

Table 1. The lattice parameters and volume per atom in graphite, as well as the corresponding Birch-Murnaghan equation of state (EOS) parameters, assuming $K_{0 x}{ }^{\prime}=4$ are listed. Uncertainties are given in parentheses. Note that for $\mathrm{H}$-graphite, $K_{0 a} \gg K_{0 c}$, is indicative of the highly anisotropic nature of graphite

\begin{tabular}{c|c|c|c|c|c|c}
\hline$a_{0}, \AA$ & $K_{0 a}, \mathrm{GPa}$ & $c_{0}, \AA$ & $K_{0 c}, \mathrm{GPa}$ & $V_{0}, \AA^{3}$ & $K_{0}, \mathrm{GPa}$ & Reference \\
\hline $2.462(0.001)$ & $442(6)$ & $6.721(0.002)$ & $12.0(0.1)$ & $8.817(0.011)$ & $57.3(0.8)$ & {$[16]$} \\
$2.461(\mathrm{NA})$ & $516(41)$ & $6.708(\mathrm{NA})$ & $14.9(0.5)$ & $8.797(\mathrm{NA})$ & $67.4(3.8)$ & {$[50]$} \\
$2.459(0.004)$ & $481(32)$ & $6.706(0.003)$ & $11.9(0.1)$ & $8.78(0.01)$ & $51.2(1.4)$ & {$[42]$} \\
$2.462(\mathrm{NA})$ & $449.7(5.1)$ & $6.707(\mathrm{NA})$ & $13.1(0.3)$ & $8.802(\mathrm{NA})$ & $59.6(1.1)$ & {$[48]$} \\
\hline
\end{tabular}

The first XRD measurement attempts of the post-graphite phase yielded an interpretation of a cubic structure [28] for a sample synthesized at high pressure and room temperature and quenched to room temperatures. Since then, the cubic structure has not been reproduced and the initial identification was likely spurious [13]. Additionally, the room-temperature high-pressure post-graphite phase has not 
been measured upon quench and all samples heated to temperatures less than $\sim 1300 \mathrm{~K}$, revert back to graphite (e.g., $[13,16,38,42])$.

In 1966, Lynch and Drickamer [50], conducted XRD measurements on graphite and found the phase transition at $\sim 16 \mathrm{GPa}$, where the compressibility of the $a$-axis of graphite became stiffer than diamond. In 1989, Hanfland et al. [42] measured the XRD of graphite and found that above $\sim 14 \mathrm{GPa}$, a phase transition occurred but the XRD pattern quality became too poor to be able to identify a structure. Soon after, Zhao and Spain [48], found similar results, although with the phase transition occurring at a slightly lower pressure of $\sim 11 \mathrm{GPa}$.

With the advent of synchrotron radiation and the increased X-ray flux, the hopes of identifying the structure of the post-graphite phase were renewed. Rather than taking 5-15 days to collect a single XRD pattern with an X-ray laboratory source [48], the intense early synchrotron sources provided sufficient flux so that measurement times dropped to $10 \mathrm{~s}$ of minutes to hours [49, 51]. Even so, the structure remained elusive.

More recently, there have been two studies [16, 40], which have measured the XRD of the post-graphite phase with modern synchrotron sources with increased flux and monochromatic energy. The first of these studies [40] spurred numerous theoretical studies to predict the nature of the new structure and yielded more than 9 candidate structures: bct- $\mathrm{C}_{4}$ [52], H- [53], K $4^{-}$[54], M- [55, 56], R- [57], S- [53] T- [58], W- [59], Z-carbon [60], and other Z-series carbon polymorphs [61]. For a complete review of the structures and respective energetics, please see the review article in this Special Issue [14, 15]. Wang et al. [16] waited a long time (at least 6 hours to as long as 1 year) between XRD pattern collections due to the sluggish nature of the transition (Fig. 5). Patience yielded quality XRD patterns that allowed discrimination between the numerous predictions (Fig. 6). From the long-duration patterns, the M-carbon structure was found to be the most consistent structure (Fig. 1, $d$ ), as compared with every other predicted structure [16].

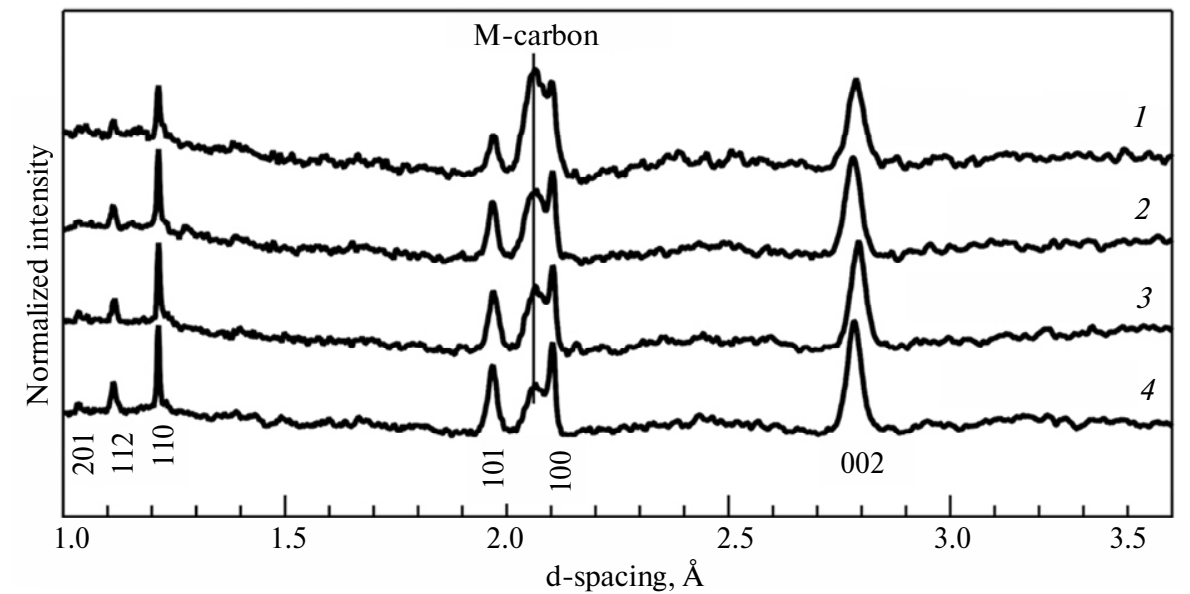

Fig. 5. XRD patterns collected at pressures of 24.9 and $26.3 \mathrm{GPa}$ immediately as well as after 9 and 6.3 hours, respectively: (1) $26.1 \mathrm{GPa}, 6.3 \mathrm{~h}$; (2) $26.3 \mathrm{GPa}$; (3) $24.6 \mathrm{GPa}, 9 \mathrm{~h}$; (4) $24.9 \mathrm{GPa}$. The increase of the intensity of $(-111)$ peak, the strongest peak of M-carbon and identified by the near vertical line near $2 \AA$, suggests that the concentration of M-carbon increases with relaxation time, confirming that the phase transformation from graphite to M-carbon is sluggish. Reproduced from [16]. 


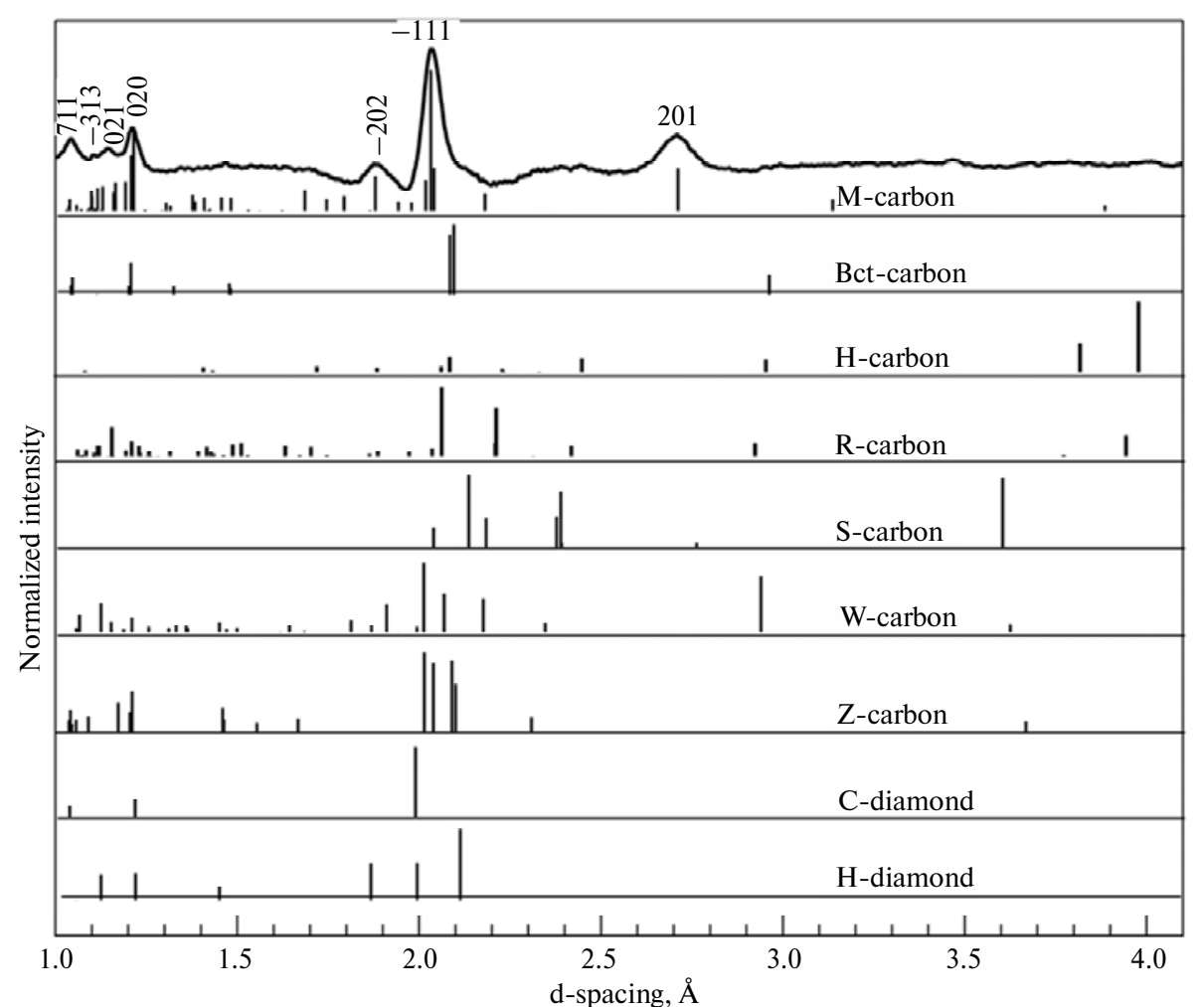

Fig. 6. XRD pattern at $\sim 50 \mathrm{GPa}$ and corresponding predicted XRD peaks for M-carbon ( $h k l$ 's used to determine volume are labeled), bct- $\mathrm{C}_{4}$ [52], H-carbon [53], R-carbon [57], S-carbon [53], W-carbon [59], Z-carbon [60], cubic diamond (C-diamond) [71] and hexagonal diamond (Hdiamond) [72] are shown as vertical lines. Figure reproduced from [16].

\section{MECHANICAL PROPERTIES}

\section{Equation of state}

The EOS of a solid gives the relationship between volume and pressure. One such EOS developed by Birch [62], building upon the work of Murnaghan [63], is derived from the theory of finite strain and works well for most solid materials. The third-order Birch-Murnaghan EOS $[62,64]$ is given by:

$$
P=3 f(1+2 f)^{5 / 2} K_{0}\left[1+f\left(\frac{3}{2} K_{0}^{\prime}-6\right)\right] \text {, }
$$

where $f=\frac{1}{2}\left[\left(\frac{V}{V_{0}}\right)^{-2 / 3}-1\right]$.

$V_{0}$ and $V$ are the unit-cell volumes at ambient and high-pressure conditions, respectively, and $K_{0}$ and $K_{0}{ }^{\prime}$ are ambient isothermal bulk modulus and its pressure derivative, respectively. A second-order Birch-Murnaghan EOS occurs when $K_{0}{ }^{\prime}$ is set to a value of 4 , thus truncating the pressure relationship. The lattice parameters can also be fit individually to a Birch-Murnaghan-like formulism by replacing $V$ and $V_{0}$ with $a^{3}$ and $a_{0}{ }^{3}, b^{3}$ and $b_{0}{ }^{3}$, and $c^{3}$ and $c_{0}{ }^{3}$ respectively, yielding each a linear modulus $K_{0 a}, K_{0 b}$ and $K_{0 c}$, with corresponding pressure derivatives $K_{0 a}{ }^{\prime}, K_{0 b}{ }^{\prime}$ and $K_{0 c}{ }^{\prime}$ [65]. The bulk modulus is a measure of how incompressible a material is. 
The equation of state of $\mathrm{H}$-graphite has been determined experimentally by using synchrotron XRD coupled with DAC $[16,42,48,50,66]$ and large volume high-pressure apparatuses [50] (Table 1). Numerous theoretical computations have been conducted to characterize the mechanical properties of M-carbon, but only one set of experimental data is available thus far to validate the predictions [16]. Nevertheless, both experiment and computations show that M-carbon has extremely low compressibility comparable to other stiff materials such as cubic$\mathrm{BN}(387 \pm 4 \mathrm{GPa})$ [67] and $\mathrm{ReB}_{2}(334 \pm 23 \mathrm{GPa})$ [68] (Table 2). Additionally, like graphite, M-carbon also shows anisotropy in compressibility along lattice axes $a, b$, and $c$, although to a lesser extent than graphite.

Table 2. Experimental and theoretical values for lattice parameters and volume/atom in M-carbon as well as the corresponding BirchMurnaghan EOS parameters. Uncertainties are given in parentheses. Where values are not available or given, NA is noted

\begin{tabular}{|c|c|c|c|c|c|c|c|c|c|c|c|}
\hline$a, \AA$ & $\begin{array}{l}K_{0 a} \\
\mathrm{GPa}\end{array}$ & $b, \AA$ & $\begin{array}{l}K_{0 b} \\
\mathrm{GPa}\end{array}$ & $c, \AA$ & $\begin{array}{l}K_{0 c} \\
\mathrm{GPa}\end{array}$ & $\beta, \operatorname{deg}$ & $V_{0}, \AA^{3}$ & $\begin{array}{c}K_{0} \\
\mathrm{GPa}\end{array}$ & $\begin{array}{l}K_{0}^{\prime}, \\
\mathrm{GPa}\end{array}$ & Method & $\begin{array}{l}\text { Refer- } \\
\text { ence }\end{array}$ \\
\hline $\begin{array}{c}9.123 \\
(0.001)\end{array}$ & $527(2)$ & $\begin{array}{c}2.559 \\
(0.001)\end{array}$ & $271(1)$ & $\begin{array}{c}4.088 \\
(0.001)\end{array}$ & 267 (1) & $\begin{array}{l}97.38 \\
(0.79)\end{array}$ & $\begin{array}{c}5.86 \\
(0.01)\end{array}$ & $\begin{array}{l}368 \\
(1)\end{array}$ & 4 & $\begin{array}{c}\text { Experi- } \\
\text { ment, } \\
\text { DAC }\end{array}$ & [16] \\
\hline $\begin{array}{l}9.089 \\
\text { (NA) }\end{array}$ & NA & $\begin{array}{l}2.496 \\
\text { (NA) }\end{array}$ & NA & $\begin{array}{l}4.104 \\
\text { (NA) }\end{array}$ & NA & $\begin{array}{l}96.96 \\
\text { (NA) }\end{array}$ & $\begin{array}{l}5.78 \\
\text { (NA) }\end{array}$ & $\begin{array}{l}431.2 \\
\text { (NA) }\end{array}$ & NA & $\begin{array}{c}\text { Theory, } \\
\text { LDA }\end{array}$ & [55] \\
\hline NA & NA & NA & NA & NA & NA & NA & $\begin{array}{l}5.991 \\
\text { (NA) }\end{array}$ & $\begin{array}{c}398 \\
\text { (NA) }\end{array}$ & 3.61 & $\begin{array}{c}\text { Theory, } \\
\text { GGA }\end{array}$ & [72] \\
\hline NA & NA & NA & NA & NA & NA & NA & $\begin{array}{l}5.745 \\
\text { (NA) }\end{array}$ & $\begin{array}{c}422 \\
\text { (NA) }\end{array}$ & 3.77 & $\begin{array}{c}\text { Theory, } \\
\text { LDA }\end{array}$ & [72] \\
\hline
\end{tabular}

\section{Mechanical strength}

Although graphite, in its natural state, is a soft material, once transformed to its cold-compressed structure, it becomes superhard with the capacity to indent the diamond anvils at relatively low pressures $(<30 \mathrm{GPa})[16,40]$. Upon quenching the sample to ambient conditions and opening the DAC, cracks along the sample boundary were observed on the diamond culets. The damage to the anvils correlates with the highest pressures reached during the measurements (Fig. 7). At

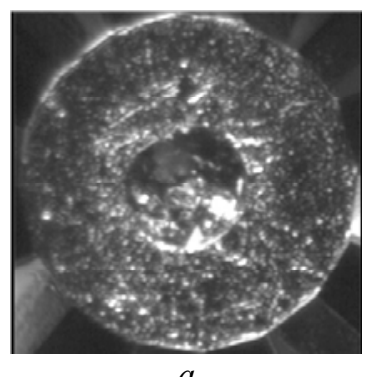

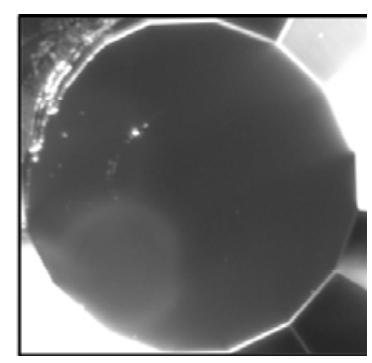

$b$

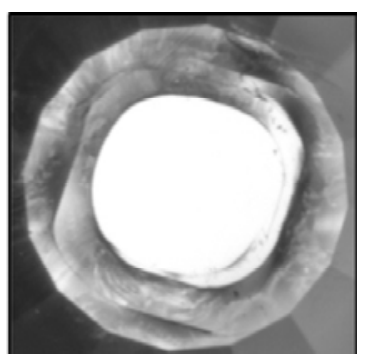

Fig. 7. Photomicrographs of diamond anvils after experiencing various high-pressure conditions. The culets are $300 \mu \mathrm{m}$ in diameter. (a) Image of the gasket filled with HOPG prior to compression. (b) Slightly scratched surface of diamond after reaching a maximum pressure of $32 \mathrm{GPa}$. The photomicrograph was taken with reflected light. (c) Badly fractured anvil by M-carbon after reaching a maximum pressure of $50 \mathrm{GPa}$. The image was taken with transmitted light. Reproduced from [16]. 
$32 \mathrm{GPa}$, only a microcrack was left on the anvil's surface; however, after compression to $50 \mathrm{GPa}$, the anvils were severely fractured. These observations suggest that M-carbon has super strength and hardness rivaling that of diamond, and is capable of deforming and indenting the diamond when the two materials are pressed against each other under nominal compression. One parameter to evaluate a material's strength is its hardness, however, M-carbon has not been recovered at ambient conditions, thus a hardness measurement is lacking. However, the hardness obtained from theoretical computations (83.1 GPa [55], $91.5 \mathrm{GPa}$ [58]) suggest that this high-pressure graphite phase is a superhard material.

\section{CONCLUSIONS}

Although carbon may appear simple and common, it is indeed, non-trivial and often leads to controversial results even when investigated with state-of-the-art computational and experimental methods. The history of graphite under high pressures is replete with disputes and controversies. Although the phase transition of graphite under cold compression has been observed by a series of experimental approaches, largely due to its complicated chemistry, detailed and accurate information regarding the room-temperature high-pressure graphite phase was unknown for a long time. After more than fifty years of effort, major progress has been achieved with the identification of the crystal structure of the post-graphite phase, namely M-carbon, which was predicted by theoretical computations [55] and later confirmed by XRD measurements [16]. This newly-identified phase has the extraordinary ability to damage diamond, however, its unquenchable nature makes ex-situ measurements, for example, hardness measurements, very challenging. Therefore, although we have reached a milestone in the study of graphite by confirming the crystal structure of the post-graphite phase, we should keep in mind that many of its properties remain enigmatic and thus it may be awhile before the strengths of M-carbon are realized in science or industry. Among the many technical difficulties, one basic requirement for the eventual application of M-carbon is the ability to stabilize it at ambient conditions. Additionally, as kinetics appear to be very important in the room-temperature post-graphite transition, the nature of the synthesis conditions and starting material may also affect the manufacture of metastable phases. However, the kinetics of the transition to M-carbon has been recently found to be more favorable than the same transition of graphite to either diamond, bct- $\mathrm{C}_{4}, \mathrm{~W}$-carbon or other $s p^{3}$ forms of carbon [69].

\section{ACKNOWLEDGEMENTS}

We are grateful for the support of the Carnegie/DOE Alliance Center (CDAC). We thank Boris Kiefer, Lowell Miyagi and Jeffrey Montgomery for many discussions on the nature of carbon.

В останні роки було проведено велику кількість чисельних досліджень, що прогнозують основні властивості графіту, підданого стисненню при кімнатній температурі, в результаті чого виникає загальновідомий “алфавітний суп” з вуглецевих структур (наприклад, bct- $C_{4}, K_{4}^{-}, M_{-}, H-, R-, S$-, $T$-, $W$-i Z-вуглець). Тоді як теоретичні методи стали більш досконалими, природа, притаманна графіту (тобто низьке Z), $i$ подальший фазовий перехід при кімнатній температурі і високому тиску (низькосиметричний, нанокристалічний $i$ млявий) роблять експериментальні вимірювання важко здійсненними і їх складно інтерпретувати навіть із застосуванням сучасної технології, щзо використовує 3-е покоління синхротронних джерел. 3 а минулі 50 років фазовий перехід графіту при кімнатній температурі і високому тиску був виявлений багатьма видами експериментів, таких як вимірювання електроопору, оптична мікроскопія, дифракиія рентгенівських променів, непружсе розсіювання рентгенівських променів і раманівська 
спектроскопія. Однак з дня його відкриття більше 50 років тому ідентифікація та отримані характеристики графіту високого тиску повні суперечностей. Недавні експерименти підтверджують, ш⿻ ия фаза має моноклинну структуру, узгоджується з Мвуглецевої фазою, передбаченою теоретичними розрахунками. Поки експерименти демонструють, щуо фазовий перехід є повільним, а при розпізнаванні фазових границь важливе значення має кінетика процесу. Крім того, пост-графітова фаза є надтвердою, за твердістю близькою до алмазу.

Ключові слова: фаза високого тиску графіmу, пост-графітова фаза, фазовий перехід, М-вуглець, експерименти з використанням алмазного ковадла.

В последние годы было проведено большое количество численных исследований, предсказывающчх основные свойства графита, подвергнутого сжатию при комнатной температуре, в результате чего возникает пресловутый “алфавитный суп” из углеродных структур (например, bct- $C_{4}, K_{4^{-}}, M-, H-, R-, S-, T-, W-u Z$-углерод). $B$ то время как теоретические методы стали более совериенными, природа, присущая графиту (т. е. низкое Z), и последующий фазовый переход при комнатной температуре и высоком давлении (низкосимметричный, нанокристаллический и вяльй) делают экспериментальные измерения трудно выполнимыми и их сложно интерпретировать даже с применением современной технологии, используюшей 3-е поколение синхротронных источников. За прошедшие 50 лет фазовый переход графита при комнатной температуре и высоком давлении был обнаружен многими видами экспериментов, таких как измерения электросопротивления, оптическая микроскопия, дифракция рентгеновских лучей, неупругое рассеяние рентгеновских лучей и рамановская спектроскопия.. Однако со дня его открытия более 50 лет назад идентификация и полученные характеристики графита высокого давления полны противоречий. Недавние эксперименты подтверждают, что эта фаза имеет моноклинную структуру, согласуюшуюся с М-углеродной фазой, предсказанной теоретическими расчетами. Пока эксперименты демонстрируют, что фазовый переход является медленным, а при распознавании фазовых границ важное значение имеет кинетика проиесса. Кроме того, пост-графитовая фаза является сверхтвердой, по твердости близкой алмазу.

Ключевые слова: фаза высокого давления графита, пост-графитовая фаза, фазовый переход, М-углерод, эксперименты с использованием алмазных наковален.

1. Caroll B.,Ostlie D. An Introduction to Modern Astrophysics. - San Francisco, California, US: Benjamin-Cummings Publishing Company, 2007. - $1278 \mathrm{p}$.

2. Harper H. A., Rodwell V.W., Mayes P. A. Review of Physiological Chemistry. - Los Altos, California, US: Lange Medical Publications, 1977. - 681 p.

3. Cao M., Woodward F. I. Dynamic responses of terrestrial ecosystem carbon cycling to global climate change // Nature. - 1998. - 393, N 6682. - P. 249-252.

4. Brown M. A., Levine M. D., Short W., Koomey J. G. Scenarios for a clean energy future // Energy Policy. - 2001. - 29, N 14. - P. 1179-1196.

5. Neves A. J., Nazaré M. H. Properties, Growth and Applications of Diamond. - London, UK: Institution of Engineering and Technology, 2001. - P. 142-147.

6. Pan L., Kania D. Diamond: Electronic Properties and Applications. - Boston, US: Kluwer, 1995. $-472 \mathrm{p}$.

7. Chung D. D. L. Review graphite // J. Mater. Sci. - 2002. - 37, N 8. - P. 1475-1489.

8. Pierson H. O. Handbook of Carbon, Graphite, Diamond and Fullerenes. - Park Ridge, New Jersey, US: Noyes Publications, 1993. - 398 p.

9. Bovenkerk H. P., Bundy F. P., Hall H. T. et al. Preparation of diamond // Nature. - 1959. 184, N 4693. - P. 1094-1098.

10. Carlson R. W. The Mantle and Core. - New York: Elsevier, 2005. - 248 p.

11. Bundy F. P., Hall H. T., Strong H. M., Wentorf R. H., Jr. Man-made diamonds // Nature. 1955. - 176, N 4471. - P. 51-55.

12. Frondel C., Marvin U. B. Lonsdaleite, a hexagonal polymorph of diamond // Ibid. - 1967. 214, N 5088. - P. 587-589.

13. Bundy F. P., Kasper J. S. Hexagonal diamond - a new form of carbon // J. Chem. Phys. 1967. - 46, N 9. - P. 3437-3446. 
14. Boulfelfel S. E., Zhu Q., Oganov A. R. Novel $s p^{3}$-forms of carbon predicted by evolutionary metadynamics and analysis of their synthesizability using transition path sampling // $\mathrm{J}$. Superhard Mater. - 2012. - 34, N 6. - P. 350-359.

15. He C., Su L. Z., Zhong J. Prediction of superhard carbon allotropes from a segment combination method // Ibid. - 2012. - 34, N 6. - P. 386-399.

16. Wang Y., Panzik J. E., Kiefer B., Lee K. K. M. Crystal structure of graphite under roomtemperature compression and decompression // Sci. Reports. - 2012. - 2, art. 520.

17. Lin Y., Zhang L., Mao H. K. et al. Amorphous diamond: a high-pressure superhard carbon allotrope // Phys. Rev. Lett. - 2011. - 107, N 17, art. 175504.

18. Wang Z., Zhao Y., Tait K. et al. A quenchable superhard carbon phase synthesized by cold compression of carbon nanotubes // PNAS. - 20041. - 101, N 3. - P. 13699-13703.

19. Brazhkin V.V., Lyapin A. G. Hard and superhard carbon phases synthesized from fullerites under pressure // J. Superhard Mater. - 2012. - 34, N 6. - P. 400-423.

20. Kurio A., Tanaka Y., Sumiya H. et al. Wear resistance of nano-polycrystalline diamond with various hexagonal diamond contents // Ibid. - 20121. - 34, N 6. - P. 343-349.

21. Zhao Z., Zhou X.-F., Hu M. et al. High-pressure behaviors of carbon nanotubes // Ibid. 2012. - 34, N 6. - P. 371-385.

22. Bundy F. P. The $p, T$ phase and reaction diagram for elemental carbon, 1979 // J. Geophys. Res. $-1980 .-85$, N B12. - P. 6930-6936.

23. Clarke R., Uher C. High-pressure properties of graphite and its intercalation compounds // Adv. Phys. - 1984. - 33, N 5. - P. 469-566.

24. Bundy F. P., Bassett W. A., Weathers M. S. et al. Review article: the pressure-temperature phase and transformation diagram for carbon; updated through 1994 // Carbon. - 1996. - 34, N 2. - P. 141-153.

25. Badding $J$. V., Lueking A. D. Reversible high pressure $s p^{2}-s p^{3}$ transformations in carbon // Phase Transitions. - 2007. - 80, N 10-12. - P. 1033-1038.

26. Samara G. A, Drickamer H. G. Effect of pressure on resistance of pyrolytic graphite // J. Chem. Phys. - 1962. - 37, N 3. - P. 471-474.

27. Balchan A. S., Drickamer H. G. High Pressure electrical resistance cell, and calibration points above 100 kilobars // Rev. Sci. Instrum. - 1960. - 32, N 3. - P. 308-313.

28. Aust R. B., Drickamer H.G. Carbon - a new crystalline phase // Science. - 1963. - 140, N 3568. - P. 817-819.

29. Okuyama N., Yasunaga H., Minomura S., Takeya K. Dependence of the resistance on pressure in the $c$-direction of pyrolytic and natural graphite // Jpn. J. Appl. Phys. - 1971. - 10, N 11. - P. 1645-1646.

30. $\mathrm{Li}$ X., Mao H. K. Solid carbon at high pressure: electrical resistivity and phase transition // Phys. Chem. Minerals. - 1994. - 21, N 1. - P. 1-5.

31. Liebermann R., Wang $Y$. Characterization of sample environment in a uniaxial split-sphere apparatus // High-Pressure Research: Application to Earth and Planetary Sciences / Eds. Y. Syono, M. N. Manghnani. - Washington, DC: Am. Geophys. Un., 1992. - P. 19-31. 1992, pp. 19-30.

32. Mao H. K., Bell P. M. Techniques of Electrical Conductivity Measurement to $300 \mathrm{Kbar}$, New York, US: Academic, 1977. - P. 493-502.

33. Montgomery J. M., Kiefer B., Lee, K. K. M. Determining the high-pressure phase transition in highly-ordered pyrolitic graphite with time-dependent resistance measurements // J. Appl. Phys. - 2011. - 110, N 4, art. 043725.

34. Utsumi $W$., Yagi T. Light-transparent phase formed by room-temperature compression of graphite // Science. - 1991. - 252, N 5012. - P. 1542-1544.

35. Goncharov A. F., Makarenko I. N., Stishov S. M. Graphite at pressures up to $55 \mathrm{GPa}$ : optical properties and raman spectra // High Press. Res. - 1990. - 4, N 1-6. - P. 345-347.

36. Goncharov A. F., Makarenko I. N., Stishov S. M. Graphite at pressures up to $55 \mathrm{GPa}$ : optical properties and Raman scattering - amorphous carbon? // Sov. Phys. JETP. - 1989. - 69, N 2. - P. 380-381.

37. Goncharov A. F. Observation of amorphous phase of carbon at pressures above $23 \mathrm{GPa} / /$ JETP Lett. - 1990. - 51, N 7. - P. 418-421.

38. Hanfland M., Syassen K., Sonnenschein R. Optical reflectivity of graphite under pressure // Phys. Rev. B. - 1989. - 40, N 3. - P. 1951-1954.

39. Miller E. D., Nesting D. C., Badding J. V. Quenchable transparent phase of carbon // Chem. mater. - 1997. - 9, N 1. - P. 18-22. 
40. Mao W. L., Mao H., Eng P. J. et al. Bonding changes in compressed superhard graphite // Science. - 2003. - 302, N 5644. - P. 425-427.

41. Xu J., Mao H., Hemley R. The gem anvil cell: high-pressure behavior of diamond and related materials // J. Phys: Condens. Matter. - 2002. - 14, N 44. - P. 11549-11552.

42. Hanfland M., Beister H., Syassen K. Graphite under pressure: equation of state and first-order raman modes // Phys. Rev. B. - 1989. - 39, N 17. - P. 12598-12603.

43. Liu Z., Wang L., Zhao Y. et al. High-pressure Raman studies of graphite and ferric chloridegraphite // J. Phys.: Condens. Matter. - 1990. - 2, N 40. - P. 8083-8088.

44. Schindler T., Vohra Y. K. A micro-Raman investigation of high-pressure quenched graphite // Ibid. - 1995. - 7, N 47. - P. L637-L642.

45. Loa I., Moschel C., Reich A. et al. Novel graphitic spheres: Raman spectroscopy at high pressures // Phys. Stat. Sol. (b). - 2001. - 223, N 1. - P. 293-298.

46. Pocsik I., Hundhausen M., Koos M., Ley L. Origin of the D peak in the Raman spectrum of microcrystalline graphite // J. Non-Cryst. Solids. - 1998. - 227-230, N 2. - P. 1083-1086.

47. Ferrari A. C., Robertson $J$. Interpretation of Raman spectra of disordered and amorphous carbon // Phys. Rev. B. - 2000. - 61, N 20. - P. 14095-14107.

48. Zhao Y. X., Spain I. L. X-ray Diffraction data for graphite to $20 \mathrm{GPa} / /$ Ibid. - 1989. - 40, N 2. - P. 993-997.

49. Yagi T., Utsumi W., Yamakata M. et al. High-pressure in situ X-ray diffraction study of the phase transfromation from graphite pyrolitic to hexagonal diamond at room temperature // Ibid. - 1992. - 46, N 10. - P. 6031-6039.

50. Lynch R. W. Drickamer H. G. Effect of high pressure on the lattice parameters of diamond, graphite, and hexagonal boron nitride // J. Chem. Phys. - 1966. - 44, N 1. - P. 181-184.

51. Kim $\mathrm{Y}$., $\mathrm{Na} \mathrm{K}$. High pressure X-Ray diffraction study on a graphite using synchrotron radiation // J. Petrol. Soc. Korea. - 1994. - 3, N 1. - P. 34-40.

52. Umemoto K., Wentzcovitch R. M., Saito S., Miyake T. Body-centered tetragonal $\mathrm{C}_{4}$ : a viable $s p^{3}$ carbon allotrope // Phys. Rev. Lett. - 2010. - 104, N 12, art. 125504.

53. He C., Sun L. Z., Zhang, C. X. et al. New superhard carbon phases between graphite and diamond // Solid State Comm. - 2012. - 152, N 16. - P. 1560-1563.

54. Itoh M., Kotani M., Naito H. et al. New metallic carbon crystal // Phys. Rev. Lett. - 2009. 102, N 5, art. 055703.

55. Li Q., Ma Y., Oganov A. R. et al. Superhard monoclinic polymorph of carbon // Ibid. 2009. - 102, N 17, art. 175506.

56. Oganov A. R., Glass C. W. Crystal structure prediction using ab initio evolutionary techniques: principles and applications // J. Chem. Phys. - 2006. - 124, N 24, art. 244704.

57. Niu H., Chen X., Wang S. et al. Families of superhard crystalline carbon allotropes constructed via cold compression of graphite and nanotubes // Phys. Rev. Lett. - 2012. - 108, N 13, art. 135501.

58. Sheng X. L., Yan Q. B., Ye F. et al. T-carbon: a novel carbon allotrope // Ibid. - 2011. - 106, N 15, art. 155703.

59. Wang J. T., Chen C., Kawazoe Y. Low-temperature phase transformation from graphite to $s p^{3}$ orthorhombic carbon // Ibid. - 2011. - 106, N 7, art. 075501.

60. Amsler M., Flores-Livas J. A., Lehtovaara L. et al. Crystal structure of cold compressed graphite // Ibid. - 2012. - 108, N 6, art. 065501.

61. Wang J. T., Chen C. F., Kawazoe Y. Orthorhombic carbon allotrope of compressed graphite: ab initio calculations // Phys. Rev. B. - 2012. - 85, N 3, art. 033410.

62. Birch F. Finite strain isotherm and velocities for single-crystal and polycrystalline $\mathrm{NaC} 1$ at high pressures and $300 \mathrm{~K} / /$ J. Geophys. Res. - 1978. - 83, N B3. - P. 1257-1268.

63. Murnaghan F. D. Finite deformations of an elastic solid // Amer. J. Math. - 1937. - 59, N 2. - P. 235-260.

64. Jeanloz R. Finite-strain equation of state for high-pressure phases // Geophys. Res. Lett. 1981. - 8, N 12. - P. 1219-1222.

65. Xu H., Zhao Y., Zhang J. et al. Anisotropic elasticity of jarosite: a high-p synchrotron XRD study // Am. Mineral. - 2010. - 95, N 1. - P. 19-23.

66. Nakayama A., Iijima S., Koga Y. et al. Compression of polyhedral graphite up to $43 \mathrm{GPa}$ and $\mathrm{X}$-Ray diffraction study on elasticity and stability of the graphite phase // Appl. Phys. Lett. 2004. - 84, N 25. - P. 5112-5114.

67. Goncharov A. F., Crowhurst J. C., Dewhurst J. K. et al. Thermal equation of state of cubic boron nitride: implications for a high-temperature pressure scale // Phys. Rev. B. - 2007. - 75, N 22, art. 224114. 
68. Wang Y., Zhang J., Daemen L. L. et al. Thermal equation of state of rhenium diboride by high pressure-temperature synchrotron X-ray studies // Ibid. - 2008. - 78, N 22, art. 224106.

69. Boulfelfel S. E., Oganov A. R., Leoni S. Understanding the nature of "superhard graphite" // Sci. Rep. -2012 . 22, art. 471.

70. NRL, The Diamond (A4) Crystal Structure, 2008.

71. Occelli F., Loubeyre P., Letoullec R. Properties of diamond under hydrostatic pressures up to $140 \mathrm{GPa} / /$ Nature Mater. - 2003. - 2, N 3. - P. 151-154.

72. Liang Y., Zhang $W$., Chen L. Phase stabilities and mechanical properties of two new carbon crystals // EPL. - 2009. - 87, N 5, art. 56003.

Department of Physics, Oakland University

Received 21.09.2012

Department of Geology \& Geophysics,

Yale University 